\title{
The Relationship of Human Resource Practices (HRP) Constructs With Turnover Intention Among Employees in Sarawak, Malaysia
}

\author{
Mark Kasa ${ }^{1}$, Choi-Meng Leong ${ }^{2}$, Joseph Pudun ${ }^{1}$, Sheena Poh $^{1} \&$ Nursyafiqah Ramli ${ }^{1}$ \\ ${ }^{1}$ Faculty of Hospitality \& Tourism Management, UCSI University Malaysia, Malaysia \\ ${ }^{2}$ Faculty of Business and Management, UCSI University Malaysia, Malaysia \\ Correspondence: Mark Kasa, Faculty of Hospitality \& Tourism Management, UCSI University Malaysia, Malaysia.
}

Received: July 19, 2020

doi:10.5430/rwe.v12n1p43
Accepted: August 25, 2020

Online Published: January 3, 2021

URL: https://doi.org/10.5430/rwe.v12n1p43

\begin{abstract}
Competition within the service industry is getting more intense due to privatisation and rising number of business entities creating toward competitiveness in the market. The banking sector is known as one of the service industries with a high rate of turnover in Malaysia. Some of the reason employees choose to leave an organisation are such as arduous and strenuous job environment as well as demanding workloads. When more and more employees leave the organization, it will cause unfavourable impacts on a bank's performance and productivity. Previous literatures have revealed the relatedness of human resource practices (HRP) with turnover intention (TI). 283 questionnaires have been distributed to bank employees in Kuching, Malaysia. The collected data was analysed in the aspects of correlation and regression where the results show that HRP are negatively related to employee's turnover intention. Results from the research demonstrated the importance for bank employers to further enhance its existing HRP to minimize employees' turnover intentions. Furthermore, implications as well as recommendation for future study are also provided by this research. This study extends the knowledge of the effectiveness of human resource practices by incorporating the various effects of human resources practices on turnover intention from the employee perspective. This study also recommended few strategies for enhancement of present HRP to lower bank employees' intention to quit the job.
\end{abstract}

Keywords: human resource practices, turnover intention, banking industry

\section{Introduction}

Employee turnover is momentous and lingering entanglement faced by most organizations. According to Bares (2005) and Keni et al. (2013), the banking industry had the highest turnover rate in both the United States and Malaysia. High employee turnover can lead to employment costs (Choi et al., 2012) and negatively affect performance, operation expenses as well as margin of an organization (Dwomoh \& Korankye, 2012; Shukla \& Sinha, 2013). There is a significant relationship between HRP and turnover intention of employees (Gould-Williams \& Mohamed, 2010). It is vital to implement HRP in a well-designed mechanism to ensure the satisfaction of employees. A prerequisite for retaining employees is employee satisfaction (Mahmud \& Idrish, 2011). Enhanced employee satisfaction can contribute towards a reduction in the cost of employee turnover and positioning of an organization as an employer of choice which captivates more competent talents (Mahmud \& Idrish, 2011). Majority of the empirical researches conducted with regards to turnover among employees were found in non-Asian context, particularly in the United States and Canada (Benson, 2006; Haines et al., 2010; Rondeau \& Wagar, 2016). In order to address this gap in literature, this present study was conducted in the state of Sarawak, Malaysia to explore the relationship of HRP on TI among the bank employees. Bank is an industry that receives increased competition recently (Chung \& Ariff, 2017). The employers in Malaysia banking industry have certain level of expectation on the employees, such as strong interpersonal and communication skills, possess experience and qualifications, and are able to fit with the vision, culture and values of their organizations (Financial Accreditation Agency, 2020). Talent shortage also prevailed in the industry (Financial Accreditation Agency, 2020). The turnover intention rate in financial and banking industry in Malaysia was as high $18.3 \%$ (Letchumanan, Apadore, \& Ramasamy, 2017). Therefore, it is critical to retain the quality staff in the industry by investigating the source of turnover among the staff. The Social Exchange Theory was being utilized as a fundamental theory for the current study. This study is organized as follows: 
first, introduction; second, literature review and hypothesis; third, methodology; fourth, results; fifth, discussions; sixthly, conclusion and implications, and lastly, limitations and future studies.

\section{Literature Review and Hypothesis}

\subsection{Performance Appraisal (PA) and Turnover Intention (TI)}

PA refers is as an assessment or evaluation process for both individual employee and teams formally (Mondy \& Martocchio, 2016). When PA is conducted effectively, it can help in stress reduction, overall performance evaluation, identify a discrepancy between the current performance by employees' and desired objectives, and includes ideas developed for any plans (Teratanavat et al., 2006). Without PA in an organization, it can engender an increase in employee's willingness to leave their current job (Laura, 1996; Abdullah et al., 2011). It was revealed in past studies that there is a correlation between satisfaction towards PA and TI (Kuvaas, 2006; Vignaswaran, 2008; Shahid, 2016). Enhanced PA process may contribute to a decline in TI (Kadiresan et al., 2015). Studies such as Kee, Ahmad and Abdullah (2016); and Falahat, Gee and Liew (2019) had utilized human resource practices to investigate turnover intention in banking industry in Malaysia. A limited number of studies concerning relatedness between PA and TI in the banking industry in Sarawak, Malaysia context was being identified. Therefore, hypothesis 1 proposed that: (H1) There is a negative relationship between PA and TI.

\subsection{Pay Satisfaction (PS) and Turnover Intention (TI)}

PS refers to the feeling - which can be either a negative of positive - of an employee concerning the payment amount they received (Miceli \& Lane, 1991). The level of satisfaction or dissatisfaction relating to the pay they received depends on the difference between employee's perception regarding the payment amount that they should or deserve to receive and their contribution of efforts for an organization (Lawler, 1971). An employee's intention to quit their job can be influence either directly or indirectly by the level of satisfaction they experience - the level of satisfaction can be affected by the job satisfaction level of an individual and the level of commitment (Lum et al., 1998). PS is one of the crucial predictors of TI (Carless, 2005). There is a greater tendency for an employee to remain with an organisation when they perceive they are receiving - in terms of payment - is equivalent to what they think they deserve and expectation (Lawler, 1986). Pay dissatisfaction can result in TI and turnover (Williams et al., 2006). Besides that, there is a relationship between an individual level of PS towards the pay they received and TI (Currall et al., 2005; Panaccio et al., 2014; Singh \& Loncar, 2010; Tran, 2016). There is limited availability of studies with regards to the effect of PA on TI among bank employees. Thus, hypothesis 2 proposed that: (H2) There is a negative relationship between PS and TI.

\subsection{Training (T) and Turnover Intention (TI)}

The purpose of $\mathrm{T}$ provision is to prepare employees with the required knowledge as well as skills for carrying out their tasks (Mondy \& Martocchio, 2016). Skills and knowledge acquired enable to help an employee to enhance their job performance of employees (Joarder \& Sharif, 2011). One of the most prevalent non-monetary rewards revealed by Sonawane (2008) was opportunities to learn new skills. Thus, an essential element in lowering the intention to quit among employees is by providing training (Reddy, 1996; Bartlett, 2001). T can help employees and employers to establish a long-lasting relationship, hence influencing an employee to become more committed to their organization and decline in TI (Samuel \& Chipunza, 2009). Nonetheless, studies that supported employees who went for specific training have lower turnover intention were relatively few (Chang,1999; Martin, 2003; Kesen, 2016). Nevertheless, only a few studies discovered that some employees may utilize training outcomes to apply for other employment opportunities with a higher salary (Green et al., 2000; Haines et al., 2010). According to the limited researches on training and TI in banking in Sarawak context, hypothesis 3 proposed that: (H3) There is a negative relationship between training and turnover intention.

\subsection{Job Autonomy (JA) and Turnover Intention (TI)}

JA is level of freedom granted to employees to decide the preferred and suitable method to perform their work tasks (Morgeson \& Humphrey, 2006). When there is autonomy in doing a job, employees can determine the method of dealing with an event, hence leads to an increase of effectiveness in solving problems (Frese \& Zapf, 1994). Furthermore, employees will also be more proactive to learn an additional set of skill as well as becoming more responsible and committed in their job endeavour (Parker, 1998). When employees experience more autonomy in terms of performing their duties, the less likely they are to quit (Iverson, 1999). Past studies demonstrated a negatively related between job autonomy and TI (Batt \& Valcour, 2003; Kim \& Stoner, 2008; Dysvik \& Kuvaas, 2013). Employees with freedom in determining their work schedule will have to experience a sense of belonging along with highly recognized the need of their job demand and reduce the tendency to quit the job (Galletta et al., 
2011). As there are diminished studies regarding JA and TI among bank employees, the hypothesis 4 proposed that: (H4) There is a negative relationship between job autonomy and turnover intention.

\begin{tabular}{|c|c|}
\hline $\begin{array}{c}\text { Human Resource Practices: } \\
\text { Performance Appraisal (PA) } \\
\text { Pay Satisfaction (PS) } \\
\text { Training (T) } \\
\text { Job Autonomy (JA) }\end{array}$ & $\begin{array}{c}\text { Turnover Intention } \\
\text { (TI) }\end{array}$ \\
\hline
\end{tabular}

Figure 1. The proposed research model

Social Exchange Theory (SET) by Blau (1964) serves as the underlying theory used to support this study. The research model proposed for this study (Figure 1) was designed using the basis of SET which utilised organizational psychology literature to examine employer and employee relationship (Blau, 1964). When numerous parties cooperate as well as receive mutual benefit, this is where the social exchange takes place (Martin, 2011). One party will be inclined to respond reciprocally in return of actions by the other party (Gouldner, 1960; Gergen, 1969). When an individual employee is satisfied, the employee mostly prone to contribute extra efforts in performing work tasks (Rhoades et al., 2001). When an organization provides favourable treatments such as satisfactory human resource practices, employees tend to repay through enhanced job performance while lower the intention to quit (Sirca et al., 2012).

\section{Methodology}

In this research, the instrument used to gather data is questionnaires designed using the English language. This study utilizes purposive sampling in which samples comprise of banking employees from 4 reputable brands located in Sarawak. The self-administrated questionnaire was distributed to the respondents. There were two sections in the questionnaire. Section A comprised of the questions related to respondents' profile while Section B consisted of 43 items measuring TI, PS, PA, T and JA; Instrument by Bozeman and Perrewe (2001) was utilized to measure TI (5 items). Instruments by Meyer and Smith (2000) was utilised to measure PA (7 items). A four-dimensional PS questionnaire (18 items) was being utilised to measure the level of PS (Heneman \& Schwab, 1985). T was being measured using 4 items by Delery and Doty (1996). For measuring JA, 9 items from the prior work of Breaugh (1985) was used. 6-likert scale was utilized to avoid neutral responses from $\mathrm{n}$ respondents (Gwinner, 2006).

\subsection{Data Analysis Methods}

This research applies the quantitative method and uses Scientific Package for Social Sciences 22 (SPSS 22) for data analysis. In total, 283 questionnaires have been gathered from respondents in the actual study. The data was checked for the outliers by using Mahalanobis distances. The critical value for four independent variables is 18.47. As a result, 5 respondents with value exceeding 18.47 were excluded in the analysis. 278 questionnaires were used for the analysis.

The reliability and validity tests were performed to scrutinize research instruments' validity and reliability as well as to rectify any possible complications from the methodology of the research. From the reliability and validity tests, all research items fulfilled the required requirements. All variable items for TI, PS, PA, T and JA with Cronbach's Alpha coefficient values of $.933, .973, .946, .920$ as well as .962 respectively. We also performed Exploratory factor analysis (EFA) for all items included in the questionnaire. The factor loading for all variables is more than .40 (Hair et al., 1998), KMO values met the acceptable standard of .70, Eigenvalue surpasses 1.0 and a p-value less than .05 for Bartlett's test of Sphericity in which illustrates the significant distinctiveness of correlation matrix from identity matrix (Hair et al., 1998). The community of all items tested using the community analysis are greater than 0.5 and therefore it can be concluded that the items were categorized into their respective groups in Table 1. Only PS4 was found falling outside the community of PS and therefore PS4 was eliminated for the analysis.

\subsection{The Estimated Model}

The explanatory variables consisted of pay satisfaction, performance appraisal, training and job autonomy while the dependent variable is turnover intention. 
The estimated model can be expressed as:

$$
T I=\beta_{0}+\beta_{1} P S+\beta_{2} P A+\beta_{3} T+\beta_{4} J A+\varepsilon
$$

where TI, PS, PA, T and JA indicates turnover intention, pay satisfaction, performance appraisal, training and job autonomy, respectively. $\beta_{0}$ is the constant factor. $\beta_{1}, \beta_{2}, \beta_{0}$ and $\beta_{0}$ are the coefficients for the factors. $\varepsilon$ designates the error term.

Table 1. Exploratory Factor Analysis

\begin{tabular}{|c|c|c|c|c|c|c|}
\hline \multicolumn{7}{|c|}{ Rotated Component Matrix } \\
\hline \multicolumn{7}{|c|}{ Component } \\
\hline & Items & 1 & 2 & 3 & 4 & 5 \\
\hline PA1 & $\begin{array}{l}\text { I am satisfied with the way my } \\
\text { organization provides me with } \\
\text { feedback }\end{array}$ & & & 0.726 & & \\
\hline PA2 & $\begin{array}{l}\text { The feedback I receive on how I do } \\
\text { my job is highly relevant }\end{array}$ & & & 0.718 & & \\
\hline PA3 & $\begin{array}{l}\text { My organization is good at providing } \\
\text { recognition for good performance }\end{array}$ & & & 0.702 & & \\
\hline PA4 & $\begin{array}{l}\text { The feedback I receive agrees with } \\
\text { what I have actually achieved }\end{array}$ & & & 0.720 & & \\
\hline PA5 & $\begin{array}{l}\text { I think that my organization attempts } \\
\text { to conduct performance appraisal the } \\
\text { best possible way }\end{array}$ & & & 0.717 & & \\
\hline PA6 & $\begin{array}{l}\text { My organization seems more engaged } \\
\text { in providing positive feedback for } \\
\text { good performance than criticizing } \\
\text { poor performance. }\end{array}$ & & & 0.712 & & \\
\hline PA7 & $\begin{array}{l}\text { Performance appraisal is valuable to } \\
\text { me as well as to my organization. }\end{array}$ & & & 0.654 & & \\
\hline PS1 & I am satisfied with my take home pay. & 0.680 & & & & \\
\hline PS2 & I am pleased with my benefit package. & 0.750 & & & & \\
\hline PS3 & $\begin{array}{l}\text { I am satisfied with my most recent } \\
\text { raise. }\end{array}$ & 0.705 & & & & \\
\hline PS5 & I am satisfied with my current salary. & 0.697 & & & & \\
\hline PS6 & $\begin{array}{l}\text { I am satisfied with the amount the } \\
\text { company pays toward my benefits. }\end{array}$ & 0.762 & & & & \\
\hline PS7 & $\begin{array}{l}\text { I am satisfied with the raises I have } \\
\text { typically received in the past. }\end{array}$ & 0.745 & & & & \\
\hline PS8 & $\begin{array}{l}\text { I am satisfied with the company's pay } \\
\text { structure. }\end{array}$ & 0.717 & & & & \\
\hline PS9 & $\begin{array}{l}\text { The company gives information about } \\
\text { pay issues of concern to me. }\end{array}$ & 0.734 & & & & \\
\hline PS10 & $\begin{array}{l}\text { I am satisfied with my overall level of } \\
\text { pay. }\end{array}$ & 0.723 & & & & \\
\hline PS11 & $\begin{array}{l}\text { I am satisfied with the value of my } \\
\text { benefits. }\end{array}$ & 0.754 & & & & \\
\hline PS12 & $\begin{array}{l}\text { Pay of other jobs in the company is } \\
\text { satisfactory. }\end{array}$ & 0.679 & & & & \\
\hline PS13 & $\begin{array}{l}\text { There is consistency in the company's } \\
\text { pay policies. }\end{array}$ & 0.733 & & & & \\
\hline PS14 & I am satisfied with the size of my & 0.709 & & & & \\
\hline
\end{tabular}


current salary.

\begin{tabular}{|c|c|c|c|c|c|}
\hline PS15 & $\begin{array}{l}\text { I am satisfied with the number of } \\
\text { benefits I receive. }\end{array}$ & 0.703 & & & \\
\hline PS16 & $\begin{array}{l}\text { I am satisfied with the way how my } \\
\text { raises are determined. }\end{array}$ & 0.710 & & & \\
\hline PS17 & $\begin{array}{l}\text { I am pleased with the differences in } \\
\text { pay among jobs in the company. }\end{array}$ & 0.600 & & & \\
\hline PS18 & $\begin{array}{l}\text { I am happy with how the company } \\
\text { administers pay. }\end{array}$ & 0.673 & & & \\
\hline $\mathrm{T} 1$ & $\begin{array}{l}\text { Employees in this job will normally } \\
\text { go through training programs every } \\
\text { few years. }\end{array}$ & & & & 0.842 \\
\hline $\mathrm{T} 2$ & $\begin{array}{l}\text { Extensive training programs are } \\
\text { provided for individuals in the job. }\end{array}$ & & & & 0.829 \\
\hline T3 & $\begin{array}{l}\text { There are formal training programs to } \\
\text { teach new hires the skills they need to } \\
\text { perform their jobs. }\end{array}$ & & & & 0.824 \\
\hline $\mathrm{T} 4$ & $\begin{array}{l}\text { Formal training programs are } \\
\text { offered to employees in order to } \\
\text { increase their "promotability" in } \\
\text { this organization. }\end{array}$ & & & & 0.809 \\
\hline JA1 & $\begin{array}{l}\text { I am allowed to decide how to go } \\
\text { about getting my job done. }\end{array}$ & & 0.788 & & \\
\hline JA2 & $\begin{array}{l}\text { I am able to choose the way to go } \\
\text { about my job. }\end{array}$ & & 0.791 & & \\
\hline JA3 & $\begin{array}{l}\text { I am free to choose the method(s) to } \\
\text { use in carrying out my work. }\end{array}$ & & 0.809 & & \\
\hline JA4 & $\begin{array}{l}\text { I have control over the scheduling of } \\
\text { my work. }\end{array}$ & & 0.760 & & \\
\hline JA5 & $\begin{array}{l}\text { I have some control over the } \\
\text { sequencing of my work activities. }\end{array}$ & & 0.755 & & \\
\hline JA6 & $\begin{array}{l}\text { My job is such that I can decide when } \\
\text { to do particular work activities. }\end{array}$ & & 0.765 & & \\
\hline JA7 & $\begin{array}{l}\text { My job allows me to modify the } \\
\text { normal way we are evaluated so that I } \\
\text { can emphasize some aspects of my job } \\
\text { and play down others. }\end{array}$ & & 0.790 & & \\
\hline JA8 & $\begin{array}{l}\text { I am able to modify what my job } \\
\text { objectives are. }\end{array}$ & & 0.740 & & \\
\hline JA9 & $\begin{array}{l}\text { I have some control over what I am } \\
\text { supposed to accomplish. }\end{array}$ & & 0.742 & & \\
\hline TI1 & $\begin{array}{l}\text { I will probably look for a new job in } \\
\text { the near future. }\end{array}$ & & & -0.818 & \\
\hline TI2 & $\begin{array}{l}\text { At the present time, I am actively } \\
\text { searching for another job in a different } \\
\text { organization. }\end{array}$ & & & -0.799 & \\
\hline TI3 & I do not intend to quit my job. & & & -0.775 & \\
\hline TI4 & $\begin{array}{l}\text { It is unlikely that I will actively look } \\
\text { for a different organization to work for } \\
\text { in the next year. }\end{array}$ & & & -0.729 & \\
\hline TI5 & $\begin{array}{l}\text { I am not thinking about quitting my } \\
\text { job at the present time. }\end{array}$ & & & -0.752 & \\
\hline
\end{tabular}




\section{Results}

\subsection{Respondents' Demographic}

Among the 283 respondents, 170 are females (60.07\%) and 113 are males (39.93\%). Majority of the respondents are between 21 to 30 years old (34.28\%), accompanied by 31 to 40 years old (29.68\%), 41 to 50 years old (20.49\%) and 51 to 60 years old (15.55\%). Next, Chinese encompass most of the respondents with a total of $164(58.30 \%)$, followed by Malay (27.21\%), Bidayuh (18\%), Iban (16\%), Indian (6\%) and others $(0.35 \%)$. Furthermore, a large proportion of respondents are married $(64.31 \%)$, accompanied by $31.10 \%$ who is single, $12 \%$ who is divorced and $0.35 \%$ who is widowed. The educational level for most of the respondents is Degree holders (47\%), followed by Diploma holders $(33.57 \%)$, Master holders $(10.60 \%)$ and others $(8.83 \%)$. Next, for salary level (in RM), most respondents have salary level above 6,500 (30.39\%), accompanied by 2,501 to 3,500 (20.49\%), 3,501 to 4,500 (17.67\%), 4,501 to 5,500 (17.67\%), 5,501 to $6,500(12.01 \%)$ and 1,501 to 2,500 (1.77\%). In terms of job level, a large proportion of respondents are working as Admin: Executive (58.66\%), accompanied by Admin: Non-executive (23.67\%), Managerial (16.61\%) and Support (1.06\%).

\subsection{Statistical Analysis of the Model}

The relationships among the variables were tested using correlation and regression analyses. The result from the correlation analysis shows that PA, PS, T, and JA were negatively related to TI. The result from the regression analysis also shows that PA, T, and PS were significantly negatively related to TI. 46.5\% of the variation in turnover intention was explained by PA, T, and PS $\left(R^{2}=0.465\right.$; F-statistic $\left.=59.433\right)$. The significance of F-statistics of PA, T and PS is jointly explained TI. In supporting the model, Gadi and Kee (2018) also discovered that human resource practices explained 40.6 percent of the variation in turnover intention. In addition, multicollinearity test was conducted in the aspects of variance inflation factor (VIF) and tolerance value to identify the potential existence of multicollinearity among the constructs. The results show that all the VIF values are lower than 5 and the value of tolerance is higher than 0.1 (Kim, 2019). Therefore, multicollinearity is not a concern in this study. Thereafter, the following model is developed for regression analysis:

$$
\begin{array}{r}
T I=7.397-0.437 P S-0.325 P A-0.238 T-0.111 J A \\
(-3.637) \quad(-3.320) \quad(-3.757) \quad(-0.079)
\end{array}
$$

The above coefficients represent the degrees of impact of pay satisfaction, performance appraisal, training, and job autonomy on turnover intention, respectively. PS possesses the highest coefficient value of -0.437 and was significant at the $\mathrm{p}<0.05$ level. This explains a one unit increase in pay satisfaction leads to a decrease of 43.7 percent in turnover intention. In addition, the coefficient values for PA and T were -0.325 and -0.238 , respectively. Both coefficients were also significant at the $\mathrm{p}<0.05$ level. These explain an increase in one unit of performance appraisal and training will lead to 32.5 percent and 23.8 percent decrease in turnover intention. However, the result shows that JA was not significant at $\mathrm{p}<0.05$ level although the coefficient value was -0.111 .

\subsection{Hypotheses Testing}

This present study has four (4) hypothesis:

Hypothesis 1 proposed that there is a negative relationship between performance appraisal and turnover intention (TI). Pearson product-moment correlation was carried out and result exhibited that both constructs are negatively related $[\mathrm{r}=-.619, \mathrm{p}=.000, \mathrm{n}=283]$. The hypothesis is also verified via regression analysis. Performance appraisal is negatively related to turnover intention $(\beta=-.255, \mathrm{p}<.05)$, in which the relationship is negative (see Table 3 ).

Hypothesis 2 proposed that there is a negative relationship between pay satisfaction and turnover intention (TI). Pearson product-moment correlation was being utilised to assess the relationship and the result shows that pay satisfaction is negatively related with TI in a significant manner $[\mathrm{r}=-.622, \mathrm{p}=.000, \mathrm{n}=283]$. As shown in Table 3 , results from the regression analysis indicates that there is a negatively significant relationship between pay satisfaction and turnover intention $(\beta=-.088, \mathrm{p}<.05)$.

Hypothesis 3 proposed that there is a negative relationship between training and turnover intention (TI). The result from Table 2 indicated that training is negatively related with turnover intention $[\mathrm{r}=-.466, \mathrm{p}=.000, \mathrm{n}=283]$. Regression analysis also provides the same evidence for both variables $(\beta=-.254, \mathrm{p}<.05)$.

Hypothesis 4 suggested that there is a negative relationship between job autonomy and turnover intention. A Pearson product-moment correlation analysis was conducted and the result shows that both the variables was negatively significantly related $[\mathrm{r}=-.517, \mathrm{p}=.000, \mathrm{n}=283]$. However, regression results in Table 3 depict that the relationship between job autonomy and turnover intention is not significant $(\beta=-.088, \mathrm{p}=.306)$. 
Table 2. Hypotheses Testing for Direct Association

\begin{tabular}{lcccccc}
\hline & & PA & PS & T & JA & TI \\
\hline PA & $\mathrm{r}$ & 1 & & & & \\
PS & $\mathrm{r}$ & $.770^{* *}$ & 1 & & & \\
$\mathrm{~T}$ & $\mathrm{r}$ & $.477^{* *}$ & $.482^{* *}$ & 1 & & \\
$\mathrm{JA}$ & $\mathrm{r}$ & $.632^{* *}$ & $.739^{* *}$ & $.386^{* *}$ & 1 & \\
$\mathrm{TI}$ & $\mathrm{r}$ & $-.608^{* *}$ & $-.631^{* *}$ & $-.480^{* *}$ & $-.523^{* *}$ & 1 \\
\hline
\end{tabular}

** Correlation is significant at the 0.01 level (1-tailed).

Table 3. Regression Analysis

\begin{tabular}{lcccccc}
\hline Variables & $\begin{array}{c}\text { Unstandardized } \\
\text { Coefficients }\end{array}$ & $\begin{array}{c}\text { Standardized } \\
\text { Coefficients }\end{array}$ & & $\mathrm{t}$ & Sig. & \multicolumn{2}{c}{ Collinearity Statistics } \\
\cline { 2 - 3 } & $\mathrm{B}$ & Beta & & & Tolerance & VIF \\
\hline (Constant) & 7.397 & & 23.873 & 0.000 & & \\
PA & -0.325 & -0.237 & -3.32 & 0.001 & 0.385 & 2.599 \\
T & -0.238 & -0.193 & -3.757 & 0.000 & 0.739 & 1.352 \\
JA & -0.111 & -0.079 & -1.185 & 0.237 & 0.444 & 2.254 \\
PS & -0.437 & -0.297 & -3.637 & 0.000 & 0.293 & 3.412 \\
\hline
\end{tabular}

R-square $=.465$, F statistics $=59.433$

\section{Discussion}

The first hypothesis statistically revealed that performance appraisal and turnover intention were significant and negatively related. Performance appraisal is utilised for formal review and evaluation of both individual and group performance (Mondy, 2010). Through performance appraisal, it helps employees in identifying, measuring, and establishing the performance standard (Ikramullah et al., 2012). The finding of this research agrees with previous studies concerning the relationship between performance appraisal and turnover intention. Past literature has also exhibited that performance appraisal is negatively associated with turnover intention (Vignaswaran, 2008, Shahid, 2016). When performance appraisal is carried out effectively, it can ensure fair compensation, improved career prospects and aids in employee retention (Abdullah et al., 2011). Effective performance appraisal can influence employee's attitudes as well as behaviours positively (Salleh et al., 2013; Rubel \& Kee, 2015). Moreover, effective performance appraisal system might have the capability to cause bank employees to experience a sense of satisfaction, motivation and eventually a decline on the intention to quit their jobs (Usman et al., 2014). Performance appraisal is typically linked with financial incentives such as pay raise, bonuses and promotions in recognition of employee's performance (Juneja, 2018). Therefore, it is crucial for human resource personnel at the banks to conduct a performance appraisal assessment in an impartially and effectively manner.

The second hypothesis indicated a significant negative relationship between pay satisfaction and turnover intention. Pay satisfaction refers to the emotional response - both negative and positive - to the payment received (Farooqui \& Nagendra, 2014). A critical job characteristic for employees is Pay satisfaction (Singh \& Loncar, 2010). The outcome of this current research concerning the relationship between pay satisfaction and turnover intention is consistent with the results of past studies. Preceding research indicated that pay satisfaction is negatively related to turnover intention (Singh \& Loncar, 2010; Panaccio et al., 2014; Tran, 2016). One of the factors that lead to employees' search for a new job opportunity is the dissatisfaction towards the pay they received (Schreurs et al., 2013). Employees are more likely to remain with an organization when adequate compensation based on the effort exerted is provided (Rubel \& Kee, 2015). Pay satisfaction leads to positive behaviours and attitudes, better engagement level and reduction in turnover intent (Memon et al., 2017). Employees are more incline to demonstrate a higher level of accountability if they are satisfied with the amount of pay the received because employees felt that their contribution in achieving organisational goals are more appreciated (Memon et al., 2017). It is crucial to practice a compensation plan that motivates and encourages employees to act in an organization's best interest 
(Ghazanfar et al., 2011). Therefore, banks should consider reviewing the salary of their employees according to a salary benchmarking scheme which compares it with their competitors to ensure the pay provided consists with the amount of effort the employees exerted.

The third hypothesis reported a significantly negative relationship between training and turnover intention. Training is provided to employees for equipping them with the necessary knowledge and skills to perform their tasks (Mondy \& Martocchio, 2016). Conducting training helps to enhance employees' work performance by granting them effective methods in completing tasks (Ceptureanu, 2016). This finding with regards to the relationship between training and turnover intention supports previous studies which found that employees who undergone designated training have a lower intention of turnover (Martin, 2003; Samuel \& Chipunza, 2009; Kesen, 2016). Training helps to create a long-lasting employer-employee relationship thus reducing the desire to resign (Samuel \& Chipunza, 2009). Training helps employees to form a perception that the organisation care about the employees' career development (Kesen, 2016). When training requirements are met, there is a greater tendency for employees to continue their employment contract with their organisation (Sinniah \& Kamil, 2017). Training is vital in attracting and retaining competent employees (Jehanzeb, Rasheed, \& Rasheed, 2013). Training motivates employees to work harder for attaining organizational objectives efficiently and effectively, thus reducing their turnover intention (Hassan et al., 2013). Therefore, it is suggested that human resource personnel at banks provide more training opportunity for employees to help them attain additional knowledge and skills to retain them.

The fourth hypothesis indicated a significant relationship between job autonomy and turnover intention. This study found that there was a significantly negative relationship between job autonomy and turnover intention. Job autonomy means the privilege of freedom provided to employees in doing their work (Rathakrishnan et al., 2016). Employee experience autonomy in doing their job when they are being empowered to allow making decisions to fulfil their job demands through the skills they possess and receives minimal intervention from their superior (Teng et al., 2018). However, the result from the regression analysis indicates the absence of a significant relationship between job autonomy and turnover intention. Thus, the finding is inconsistent with the previous findings (Thompson \& Prottas, 2005; Kim \& Stoner, 2008; Dysvik \& Kuvaas, 2013; Kim, 2016). One of the reasons can be due to job autonomy is minimal for the respondents who are mainly comprised of office and administrative staffs. Thus, the impact of job autonomy cannot be sufficiently measured.

\section{Conclusion and Implications}

When the turnover rate is high, it can impose negative implications on the performance and effectiveness of an organization (Ingersoll \& Smith, 2003). The high turnover rate can lead to the loss of talents and higher employment expenses (Loi et al., 2006). Review of past literature and this research findings exhibited that there are many similarities concerning the negative correlation between human resource practices and turnover intention. Thus, human resource practices should be managed strategically to retain employees and improve an organization's productivity.

Furthermore, results from this research indicate that human resource practices are vital in terms of reducing turnover intention among employees of the banking sector. Hence, the human resource department of banks should place greater emphasis on the importance of human resource practices. Banks need to implement enhancements to their current human resource practices to reduce or avoid employee turnover intention as turnover may lead to detrimental impacts on an organization. Human resource department should conduct performance appraisal properly and impartially to ensure the satisfaction of employees were being met. It is necessary to provide a pay level that is in accordance with employee's contribution towards the organization, thus resulting in higher pay satisfaction. Furthermore, bank employees should be provided more trainings to further enhance employee's knowledge and skills, simultaneously it may also perceive as organizational concern or interest towards employees. Besides, employees will also experience trust from the organization, therefore more likely they are to continue their job. Future research can also consider conducting the study in a different industry to explore in-depth on the relationship between human resource practices and turnover intention.

\section{Limitations and Future Studies}

This study investigates the impact of human resource practices on turnover intention among the banking staff in Sarawak, Malaysia. Further investigation in the aspects of non-monetary elements can be included as variables to determine the turnover intention among the banking staff. In addition, the sample can be expanded to cover other states in Malaysia. Thereafter, a comparison can be done between the two different states or two different countries. Moreover, future research can also consider conducting the study in a different industry to explore in-depth on the relationship between human resource practices and turnover intention. Lastly, this study only covers the staff 
personal perspective on turnover intention. For future studies, the impact of the size of household of the staff can be included to capture the psychological effect of staff on turnover intention.

\section{References}

Abdullah, A., Bilau, A. A., Enegbuma, W. I., Ajagbe, A. M., \& Ali, K. N. (2011). Evaluation of job satisfaction and performance of employees in small and medium sized construction firms in Nigeria. 2nd International Conference on Construction and Project Management, IPEDR, 15, 225-229.

Bares, A. (2015). 2015 Turnover rates by industry. Retrieved 27 April 2018, from http://www.compensationforce.com/2016/04/2015-turnover-rates-by-industry.html

Bartlett, K. R. (2001). The relationship between training and organizational commitment: a study in the health care field. Human Resource Development Quarterly, 12(4), 335-352. https://doi.org/10.1002/hrdq.1001

Batt, R., \& Valcour, M. (2003). Human resources practices as predictors of work-family outcomes and employee turnover. Industrial Relations, 42(2), 189-220. https://doi.org/10.1111/1468-232X.00287

Benson, G. S. (2006). Employee development, commitment and intention to turnover: a test of 'employability' policies in action. Human Resource Management Journal, 16(2), 173-192. https://doi.org/10.1111/j.1748-8583.2006.00011.x

Blau, P. (1964). Exchange and power in social life. New York: Wiley.

Bozeman, D. B., \& Perrewe, P. L. (2001). The effect of item content overlap on organizational commitment questionnaire: Turnover cognitions relationships. Journal of Applied Psychology, 86(1), 16-25. https://doi.org/10.1037/0021-9010.86.1.161

Breaugh, J. A. (1985). The measurement of work autonomy. Human Relations, 38(6), 551-570. https://doi.org/10.1177/001872678503800604

Carless, S. A. (2005). Person-job fit versus person-organization fit as predictors of organizational attraction and job acceptance intentions: A longitudinal study. Journal of Occupational and Organizational Psychology, 78(3), 411-429. https://doi.org/10.1348/096317905X25995

Ceptureanu, S. I. (2016) Knowledge management tools in Romanian companies. Review of International Comparative Management, 17(2), 123-129. https://doi.org/10.1515/kbo-2016-0043

Chang, E. (1999). Career commitment as a complex moderator of organizational commitment and turnover intentions. Human Relations, 52(10), 1257-1278. https://doi.org/10.1177/001872679905201002

Choi, S. L., Panniruky, P., \& Musibau, A. A. (2012). The impact of human resource management practices on employee turnover intention: A conceptual model. Interdisciplinary Journal of Contemporary Research in Business, 4(2), 629-641.

Chung, T. F., \& Ariff, M. (2017). Competition in the Malaysia's banking industry, Quo Vadis. International Journal of Economics and Management, S3, 897-920.

Currall, S. C., Towler, J. A., Judge, A. T., \& Kohn, L. (2005). Pay satisfaction and organizational outcomes. Personnel Psychology, 58(3), 613-640.

Delery, J. E., \& Doty, D. H. (1996). Modes of theorizing in strategic human resource management: Tests of universalistic, contingency, and configurational performance predictions. Academy of Management Journal, 39(4), 802-835. https://doi.org/10.2307/256713

Dwomoh, G., \& Korankye, T. (2012). Labour turnover and its impact on performance of Banks in Ghana. European Journal of Business and Management, 4(7).

Dysvik, A., \& Kuvaas, B. (2013). Perceived job autonomy and turnover intention: The moderating role of perceived supervisor support. European Journal of Work and Organizational Psychology, 22(5), 563-573. https://doi.org/10.1080/1359432x.2012.667215

Falahat, M., Gee, S. K., \& Liew, C. M. (2019). A model for turnover intention: Banking industry in Malaysia. Asian Academy of Management Journal, 24(2), 79-91.

Farooqui, S., \& Nagendra, A. (2014). The impact of person organization fit on job satisfaction and performance of the employees. Procedia Economics and Finance, 11, 122-129. https://doi.org/10.1016/S2212-5671(14)00182-8 
Financial Accreditation Agency. (2020). What banking and finance employers really want: An interview with Tom Osborne, Hays Regional Director for Malaysia. Retrieved 10 September 2020, from https://www.faa.org.my/article/what-banking-and-finance-employers-really-want-an-interview-with-tom-osborn e-hays-regional

Frese, M., \& Zapf, D. (1994). Action as the core of work psychology: A German approach. Handbook of Industrial and Organizational Psychology, 4(2), 271-340.

Gadi, P. D., \& Kee, D. H. M. (2018). Human resource management practices and turnover intention: The mediating role of perceived organizational support in tertiary institutions in Nigeria. International Journal of Engineering \& Technology, 7(3.25), 715-722.

Galletta, M., Portoghese, I., \& Battistelli, A. (2011). Intrinsic motivation, job autonomy and turnover intention in the Italian healthcare: The mediating role of affective commitment. Journal of Management Research, 3(2). https://doi.org/10.5296/jmr.v3i2.619

Gergen, K. J. (1969). The psychology of behavioral exchange. Reading, MA: Addison-Wesley.

Ghazanfar, F., Chuanmin, S., Khan, M. M., \& Bashir, M. (2011). A study of relationship between satisfaction with compensation and work motivation. International Journal of Business and Social Science, 2(1), 120-131.

Gouldner, A. W. (1960). The norm of reciprocity: A preliminary statement. American Sociological Review, 25(2), 161-178. https://doi.org/10.2307/2092623

Gould-Williams, J., \& Mohamed, R. B. (2010). A comparative study of the effects of 'best practice' HRM on worker outcomes in Malaysia and England local government. The International Journal of Human Resource Management, 21(5), 653-675. https://doi.org/10.1080/09585191003658821

Green, F., Felstead, A., Mayhew, K., \& Pack, A. (2000). The impact of training on labour mobility: Individual and firm-level evidence from Britain. British Journal of Industrial Relations, 38(2), 261-275. https://doi.org/10.1111/1467-8543.00162

Gwinner, C. (2006). Infosurv White Paper 5-point vs. 6-point Likert Scales. Retrieved 11 January 2018, from http://www.infosurv.com/wp-content/uploads/5-point-vs-6-point-Likert-Scales.pdf

Haines, V. Y., Jalette, P., \& Larose, K. (2010). The influence of human resource management practices on employee voluntary turnover rates in the Canadian non-governmental sector. Industrial and Labor Relations Review, 63(2), 228-246. https://doi.org/10.1177/001979391006300203

Hair, J. F., Anderson, R. E., Tatham, R. L., \& Black, W. C. (1998). Multivariate data analysis (5th ed.). New Jersey: Prentice Hall International Inc.

Hassan, W., Razi, A., Qamar, R., Jaffir, R., \& Suhail, S. (2013). The effect of training on employee retention. Global Journal of Management and Business Research Administration and Management, 13(6), 17-20.

Heneman, H. G. III., \& Schwab, D. P. (1985). Pay satisfaction: Its multidimensional nature and measurement. International Journal of Psychology, 20(1), 129-141. https://doi.org/10.1080/00207598508247727

Ikramullah, M., Shah, B., Khan, S., Hassan, F. S. U., \& Zaman, T. (2012). Purposes of performance appraisal system: A perceptual study of civil servants in district dera Ismail Khan Pakistan. International Journal of Business and Management, 7(3), 142-151. https://doi.org/10.5539/ijbm.v7n3p142

Ingersoll, R. M., \& Smith, T. M. (2003). The wrong solution to the teacher shortage. Educational Leadership, 60(8), 30-34.

Iverson, R. D. (1999). An event history analysis of employee turnover: The case of hospital employees in Australia. Human Resource Management Review, 9(4), 397-418. https://doi.org/10.1016/S1053-4822(99)00027-3

Jehanzeb, K., Rasheed, A., \& Rasheed, M. F. (2013). Organizational commitment and turnover intentions: impact of employee's training in private sector of Saudi Arabia. International Journal of Business and Management, 8(8), 79-90. https://doi.org/10.5539/ijbm.v8n8p79

Joarder, M. H., \& Sharif, D. M. (2011). The role of HRM practices in predicting faculty turnover intention: Empirical evidence from private universities in Bangladesh. The South East Asian Journal Management, 5(2), 159-178.

Juneja, P. (2018). Importance of performance appraisals and how to conduct them effectively. Retrieved 3 August 2018, from https://www.managementstudyguide.com/importance-of-performance-appraisals.htm 
Kadiresan, V., Selamat, M., Selladurai, S., Ramendran, C., \& Mohamed, R. (2015). Performance appraisal and training and development of human resource management practices (HRM) on organizational commitment and turnover intention. Asian Social Science, 11(24), 162-176. https://doi.org/10.5539/ass.v11n24p162

Kee, L. B., Ahmad, R., \& Abdullah, S. M. (2016). Relationship between financial compensation and organizational commitment among Malaysian bank workers. Asian Business Research, 1(1), 75.

Keni, Muthuveloo, R., Teoh, A. P., \& Rahman, R. (2013). Turnover intention trend among commercial banks in Penang, Malaysia. International Conference on Entrepreneurship and Business Management, 21-22.

Kesen, M. (2016). The impact of employee training and innovation on turnover intention: An empirical research. International Journal of Academic Research in Business and Social Sciences, 6(1), 174-185. https://doi.org/10.6007/ijarbss/v6-i1/1987

Kim, H., \& Stoner, M. (2008). Burnout and turnover intention among social workers: Effects of role stress, job autonomy and social support. Administration in Social Work, 32(3), 5-25. https://doi.org/10.1080/03643100801922357

Kim, J. H. (2019). Multicollinearity and misleading statistical results. Korean Journal of Anesthesiology, 72(6), 558-569.

Kim, Y. (2016). Music therapists' job demands, job autonomy, social support, and their relationship with burnout and turnover intention. The Arts in Psychotherapy, 51, 17-23. https://doi.org/10.1016/j.aip.2016.08.001

Kuvaas, B. (2006). Performance appraisal satisfaction and employee outcomes: Mediating and moderating roles of work motivation. The International Journal of Human Resource Management, 17(3), 504-522. https://doi.org/10.1080/09585190500521581

Laura, S. (1996). Is performance being managed for the long term?. Quality Progress, 29(2), 14.

Lawler, E. (1971). Pay and organizational effectiveness. New York: McGraw-Hill.

Lawler, E. (1986). High-involvement management. San Fransisco: Jossey-Bass Publisher.

Letchumanan, T., Apadore, K., \& Ramasamy, M. (2017). Factors influence turnover intention in commercial banks Malaysia: A theoretical model. Innovative Journal of Business and Management, 6(3), 13-21.

Loi, R., Hang-Yue, N., \& Foley, S. (2006). Linking employees' justice perceptions to organizational commitment and intention to leave: The mediating role of perceived organizational support. Journal of Occupational and Organizational Psychology, 79(1), 101-120. https://doi.org/10.1348/096317905X39657

Lum, L, J., Kervin, K., Clark, F. R., \& Sirola, W. (1998). Explaining nursing turnover intent: Job satisfaction, pay satisfaction, or organizational commitment?. Journal of Organizational Behavior, 19(3), 305-320. https://doi.org/10.1002/(SICI)1099-1379(199805)19:3\%3C305::AID-JOB843\%3E3.0.CO;2-N

Mahmud, K., \& Idrish, S. (2011). The impact of human resource management practices on turnover of bank employees in Bangladesh. World Review of Business Research, 1(2), 71-83.

Martin, C. (2003). Explaining labor turnover: Empirical evidence from UK establishments. Labor, 17(3), 391-412. https://doi.org/10.1111/1467-9914.00246

Martin, M. J. (2011). Influence of human resource practices on employee intention to quit. Doctoral Dissertation. Virgina: Virginia Polytechnic Institute and State University.

Memon, M., Salleh, R., \& Baharom, M. (2017). The mediating role of work engagement between pay satisfaction and turnover intention. International Journal of Economics, Management and Accounting, 25(1), 43-69.

Meyer, J. P., \& Smith, C. A. (2000). HRM practices and organizational commitment: Test of a mediation model. Canadian Journal of Administrative $\quad$ Sciences, $\quad 17(4), \quad 319-331$. https://doi.org/10.1111/j.1936-4490.2000.tb00231.x

Miceli, M. P., \& Lane, M. C. (1991). Antecedents of pay satisfaction: A review and extension. Research in Personnel and Human Resources Management, 9, 235-309.

Mondy, R. (2010). Human resource management. Upper Saddle River, New Jersey: Pearson Prentice Hall.

Mondy, R. W., \& Martocchio, J. (2016). Human resource management (14th ed.). Harlow Essex: Pearson. 
Morgeson, F. P., \& Humphrey S. E. (2006). The work design questionnaire (WDQ): Developing and validating a comprehensive measure for assessing job design and the nature of work. Journal of Applied Psychology, 91(6), 1321-1339. http://psycnet.apa.org/doi/10.1037/0021-9010.91.6.1321

Panaccio, A., Vandenberghe, C., \& Ayed, A. (2014). The role of negative affectivity in the relationships between pay satisfaction, affective and continuance commitment and voluntary turnover: A moderated mediation model. Human Relations, 67(7), 821-848. https://doi.org/10.1177/0018726713516377

Parker, K. S. (1998). Enhancing role breadth self-efficacy: The roles of job enrichment and other organizational interventions. Journal of Applied Psychology, 83(6), 835-852. https://doi.org/10.1037//0021-9010.83.6.835

Rathakrishnan, T., Ng, S. I., \& Tee, K. K. (2016). Turnover intentions of lecturers in private universities in Malaysia. Journal of Social Sciences and Humanities, 24(8), 129-146.

Reddy, N. V. (1996). The relationship between training and job turnover among secretarial personnel in the Florida State University System. PHD Thesis, Florida State University, USA.

Rhoades, L., Eisenberger, R., \& Armeli, S. (2001). Affective commitment to the organization: The contribution of perceived organizational support. Journal of Applied Psychology, 86(5), 825-836. https://doi.org/10.1037/0021-9010.86.5.825

Rondeau, K., \& Wagar, T. (2016). Human resource management practices and nursing turnover. Journal of Nursing Education and Practice, 6(10), 101-109. https://doi.org/10.5430/jnep.v6n10p101

Rubel, M., \& Kee, D. (2015). Perceived fairness of performance appraisal, promotion opportunity and nurse's turnover intention: The role of organisational commitment. Asian Social Science, 11(9). https://doi.org/10.5539/ass.v11n9p183

Salleh, M., Amin, A., Muda, S., \& Halim, M. A. S. A. (2013). Fairness of performance appraisal and organizational commitment. Asian Social Science, 9(2), 121-128. https://doi.org/10.5539/ass.v9n2p121v

Samuel, M. O., \& Chipunza, C. (2009). Employee retention and turnover: Using motivational variables as a panacea. African Journal of Business Management, 3(8), 410-415.

Schreurs, B. H., Guenter, D., Schumacher, I. J., Van, E., \& Notelaers, G. (2013). Pay-level satisfaction and employee out-comes: the moderating effect of employee-involvement climate. Human Resource Management, 52, 399-421. https://doi.org/10.1002/hrm.21533

Shahid, N. (2016). The relationship between human resource management practices, organizational commitment, career concern, job stress and turnover intention.

Shukla, S., \& Sinha, A. (2013). Employee turnover in banking sector: Empirical evidence. IOSR Journal of Humanities and Social Science, 11(5), 57-61. https://doi.org/10.9790/0837-1155761

Singh, P., \& Loncar, N. (2010). Pay satisfaction, job satisfaction, and turnover intent. Relations Industrielles, 65(3), 470-488. https://doi.org/10.7202/044892ar

Sinniah, S., \& Kamil, N. (2017). The influence of human resource practices on turnover intention: The case of a telecommunication company in Malaysia. Malaysian Management Review, 52(1), 45-61.

Sirca, N. T., Babnik, K., \& Breznik, K. (2012). The relationship between human resource development systems and job satisfaction. Paper presented at the Management, Knowledge and Learning International Conference, Celje, Slovenia, 20-22 June.

Sonawane, P. (2008). Non-monetary rewards: Employee choices \& organizational practices. Indian Journal of Industrial Relations, 44(2), 256-271.

Teng, M., Hassan, Z., \& Kasa, M. (2018). The relationship between job autonomy and social support with turnover intention. The European Proceedings of Social and Behavioural Sciences, 225-235. https://doi.org/10.15405/epsbs.2018.05.19

Teratanavat, R., Raitano, R., \& Kleiner, B. (2006). How to reduce employee stress. Non-profit World, 24(3), 22-24.

Thompson, C. A., \& Prottas, D. J. (2005). Relationship among organizational family support, job autonomy, perceived control, and employee well-being. Journal of Occupational Health Psychology, 10(4), 100-118. https://doi.org/10.1037/1076-8998.10.4.100 
Tran, H. (2016). The impact of pay satisfaction and school achievement on high school principals' turnover intentions. Educational Management Administration and Leadership, 45(4), 621-638. https://doi.org/10.1177/1741143216636115

Usman, M., Fan, L., Haq, M. A. U., \& Hussain, N. (2014). Outcomes of employees' reactions towards the characteristics of performance appraisal system: A case of a commercial bank in Pakistan. European Journal of Business and Management, 6(15), 110-116.

Vignaswaran, R. (2008). The relationship between performance appraisal satisfaction and employee outcomes: A study conducted in Peninsular Malaysia, 41-60.

Williams, M. L., McDaniel, M. A., \& Nguyen, N. T. (2006). A meta-analysis of the antecedents and consequences of pay level satisfaction. Journal of Applied Psychology, 91(2), 392-413. https://doi.org/10.1037/0021-9010.91.2.392

\section{Copyrights}

Copyright for this article is retained by the author(s), with first publication rights granted to the journal.

This is an open-access article distributed under the terms and conditions of the Creative Commons Attribution license (http://creativecommons.org/licenses/by/4.0/). 